Original Paper http://ajol.info/index.php/ijbcs http://indexmedicus.afro.who.int

\title{
Physical, physicochemical and nutritional profile of honey produced in nine localities in Côte d'Ivoire
}

\author{
Apollinaire Koffi YEBOUE ${ }^{1}$, Mida Roger Guy KABRAN ${ }^{1 *}$, \\ Anatolievna Elena SOROKINA ${ }^{2}$, Axel Demel ADOU ${ }^{1}$, Christian Kouadio KOUASSI ${ }^{1}$, \\ Akhanovna Janat MAMYRBEKOVA-BEKRO ${ }^{1}$ and Yves-Alain BEKRO ${ }^{1}$ \\ ${ }^{1}$ Laboratoire de Chimie Bio-Organique et de Substances Naturelles (www.lablcbosn.com) / UFR-SFA / \\ Université Nangui Abrogoua, 02 BP 801 Abidjan 02, Côte d'Ivoire. \\ ${ }^{2}$ Department of Organic Chemistry / People's Friendship University of Russia, 6 ul. MiklukhoMaklaya, 117198 \\ Moscow, Russian Federation. \\ *Corresponding author; E-mail: guymida@gmail.com
}

\author{
Received: 10-02-2021 $\quad$ Accepted: 26-04-2021 $\quad$ Published: 30-04-2021
}

\begin{abstract}
Honey is a syrupy substance produced by bees, highly rich in monosaccharides (glucose, fructose), which give it a sweet flavor. In Côte d'Ivoire, there is very little information on the honey that is produced. The current work is to our knowledge the first of its kind. Its main objective is to assess the quality of the honey produced in nine localities in Côte d'Ivoire in terms of their physicochemical composition. All of the physicochemical characteristics (refractive index, total acidity, $\mathrm{pH}$, viscosity, electrical conductivity and diastase index were within the limits established by the Codex Alimentarius Commission. The moisture content did not exceed $19.4 \%$, which would indicate that the honey samples have long-term storage capacity and resistance to fermentation. The results were also distinguished by a high sugar content ( $78.60-83.80 \%$ of dry matter of honey), mentioning their maturity and nutritional value. In addition, the sucrose content was between 2.14 and $7.61 \%$. Honey's total acidity index found between 7.50 and $24.20 \mathrm{meq} / \mathrm{kg}$, is a proof of their bactericidal activity. The low HMF content $(<60 \mathrm{mg} / \mathrm{kg})$ of most of samples taken reflects their good technological treatment and good quality. The content of fat $(0.41$ to $0.78 \mathrm{mg} / 100 \mathrm{~g})$ and protein $(0.88$ to $3.50 \%)$ certifies their acceptable nutritional qualities, with a significant energy value (from 396.39 to $402.70 \mathrm{kcal} / 100 \mathrm{~g}$ of honey). Thus, the honey collected on Ivorian territory actually meets the requirements of the standards proposed by the Codex Alimentarius Commission.
\end{abstract}

(C) 2021 International Formulae Group. All rights reserved.

Keywords: Natural honey, physical parameters, physicochemical characteristics, nutritional properties, Côte d'Ivoire.

\section{INTRODUCTION}

According to FAO, the world honey production was 1.85 million tons in 2018, including 724,000 tons produced in Asia
(Codex Secretariat, 2017). This continent is the only region in world where honey production has been increasing steadily for more than 10 years. For several years; China has been and 
still the world's leading producer of honey. In total, more than 457,000 tons of honey are produced each year in China, that's about $28.1 \%$ of the overall world production in 2018 (FAO Stat, 2020). Turkey is the second largest honey producing country with an average annual production of 114,471 tons of beehive honey products (FAO Stat, 2020). Iran occupies the third place with an annual production of 78,567 tons of honey (FAO Stat, 2020). United States comes in fourth position with a production of $4.1 \%$ (67,576 tons) (FAO Stat, 2020). Russia produces around $4 \%$ of annual world production $(65,006$ tons in 2018) (FAO Stat, 2020). The African countries' share of world production is less than 1.5\% (198,668 tons). The countries of East, Central and West Africa produce respectively $112,242,45,157$ and 21,484 tons respectively (FAO Stat, 2020). In Côte d'Ivoire, beekeeping is very poorly developed, despite the implementation of modern practices. Indeed, most Ivorian beekeepers (also called honey hunters) are still practicing their profession in a traditional manner (Kouassi et al., 2018; Savadogo et al., 2018), this might have had an impact on their productivity, which was estimated to 610 tons in 2018 (Naila et al., 2018; FAO Stat, 2020). Honey is the most precious natural food product that has no equal among other sweet products. It is highly prized by everyone because of its richness in chemical compounds and its multiple therapeutic (antimicrobial, healing, antioxidant, etc.) and prophylactic properties (De Rodriguez et al., 2004; Brudzynski, 2006). Each consumer, referring to his personal taste preferences, prefers to buy a high quality honey without risk of adulteration. However, it often happens that the production and the distribution processes of honey don't meet the quality and food safety standards in force, resulting in a deterioration of its quality (Al-Farsi et al., 2018). This situation can also influence the competitiveness of these products on the product in regional markets. It is quite difficult to unambiguously determine the quality of honey solely on the basis of organoleptic characteristics (taste, aroma) (Bertoncel et al.,
2007; Guler et al., 2007). To do this, it is necessary to determine the physicochemical parameters, which provide more and accurate description of its composition and its properties (Bogdanov et al., 2004; Aboud et al., 2011). The composition of honey can considerably vary depending on the locality of production, the season, the breed of the bees, the plant source of nectar and the storage time in the honeycomb, as well as the mode of harvesting and post-harvest storage (Al-Farsi et al., 2018). The major component of honey is sugar (glucose, fructose, maltose, trehalose, sucrose, etc.), the total content of which reaches $80 \%$ (Zaikina, 2012; Naila et al., 2018). Reducing sugars are formed in honey from sucrose, and accumulate during its maturation, which are an indicator of the maturity, good quality and the botanical origin of honey. Moisture content also marks the maturity of honey and determines its suitability for long-term storage. Mature honey has a moisture content of no more than 20\%, crystallizing into a homogeneous mass that can be stored for a long time without losing its natural benefits (Naila et al., 2018). In a natural honey, the content of hydroxymethylfurfural (HMF) refers to the quality and the safety of the technological process performed; it is also an indicator of product adulteration (Perdrix, 2003; Moussaoui, 2011; Zaikina, 2012). The diastase index characterizes the activity of amylolytic enzymes. It describes the degree of heating and storage time of honey, which has no relationship with the nature of the honey. This is because when honey is diluted with sugar syrup, the number of diastases is significantly reduced. In addition, certain types of honey (clover, white acacia, sunflower, linden, angelica, willow, cotton, sage, etc.) have a very low diastatic activity. On the other hand, buckwheat and heather honeys have a high diastatic activity (20 to 60 units) (Zaikina, 2012). Protein substances are present in honey thanks to nectar, pollen and also the bees' bodies. They are in a colloidal state and can cause a turbidity in the final honey. Furthermore, they increase the foaming power of the honey when it is bottled. They also cause 
a blackening when honey is heated. They are the basis of crystallization during storage of honey (Gonnet, 1986; Zaikina, 2012). In recent years, the consumption of honey by the Ivorian population has seen renewed interest. But, few studies have been done on the physical and physicochemical properties of honey from Côte d'Ivoire. The main objective of the present study was to evaluate the quality of honey produced in nine localities of Côte d'Ivoire through the determination of some physical, physicochemical and nutritional characteristics for an adequate comparison with the standard values.

\section{MATERIALS AND METHODS Honey samples}

Honeys from private apiaries in nine localities in different regions of Côte d'Ivoire $\left(\mathrm{M}_{1}-\mathrm{M}_{10}\right)$ and a sample of honey $\left(\mathrm{M}_{11}\right)$ purchased at market (Table 1), were studied. All samples were collected between November 2018 and April 2019 and stored in $250 \mathrm{ml}$ glass bottles in a clean place away from light and at room temperature. Some samples were chosen according to their harvested period (Bouna: $\mathrm{M}_{1}$ and $\mathrm{M}_{2}$ ).

\section{Organoleptic characteristics}

Information on organoleptic parameters was collected based on of a survey focusing mainly on some questions regarding visual and taste sensations. The questionnaire was submitted individually to 30 people between ages 24 and 40, who were selected according to the recommendations associated with a list of questions on this subject (Moussaoui, 2011).

\section{Determination of physical, physicochemical and nutritional characteristics}

Viscosity was determined using a falling ball viscometer (Ustok et al., 2007; Zeni et al., 2013). Electrical conductivity was measured on aqueous solutions of $20 \%(\mathrm{~m} / \mathrm{v})$ honey using a Jenway 4510 type electrical conductivity meter (Bogdanov et al., 2009). The $\mathrm{pH}$ was determined using a Hanna-type $\mathrm{pH}$ meter in $10 \%(\mathrm{w} / \mathrm{v})$ honey solutions. The free acidity was obtained by titrimetry with the addition of $\mathrm{NaOH}(0.1 \mathrm{M})$ up to $\mathrm{pH}=8.3$ and was expressed in meq/kg (AOAC, 2000). The soluble and insoluble dry matter and ash contents were determined gravimetrically, according to the methods described by Bodganov et al. (2009). The moisture content was determined by measuring the refractive index at $20{ }^{\circ} \mathrm{C}$ using a Leica AR Barolworld refractometer and calculated using the Chataway table (AOAC, 2000; Bogdanov et al., 1997). The measurement of diastasis index was carried out according to the method described in international standards (GOST19792, 2001). The hydroxymethylfurfural (HMF) content (in $\mathrm{mg} / \mathrm{kg}$ ) was determined by spectrophotometric method (Bogdanov et al., 1997). The content of total and reducing sugars were determined by colorimetric method based on the optical density of a solution of potassium ferricyanide $\left(\mathrm{K}_{3}\left[\mathrm{Fe}(\mathrm{CN})_{6}\right]\right)$ at 440 $\mathrm{nm}$ after reacting with the reducing sugars in honey (GOST-19792, 2001). Moreover, Kjeldahl method was used for the protein detection (Tabet, 2009; Kabré et al., 2020). Their content expressed in $\mathrm{mg} / 100 \mathrm{~g}$ of honey was obtained as indicated by the following equation (2), after obtaining the total nitrogen content expressed as a percentage and calculated by relation (1):

Nitrogen content $=\frac{\left(V_{1}-V_{0}\right) \times N \times 14,1}{m}(1)$

With $\mathrm{V}_{0}: \mathrm{HCl}$ volume required to titrate the sample (ml); $\mathrm{V}_{1}: \mathrm{HCl}$ volume required to titrate the blank (ml); $\mathrm{N}$ : $\mathrm{HCl}$ solution titer; m: sample mass (g); 14.01: nitrogen atomic mass.

Protein content $=$ Nitrogen content $\times 6,25(2)$

The fat content (MG), expressed in $\mathrm{g} / 100 \mathrm{~g}$ of honey, has been determined.

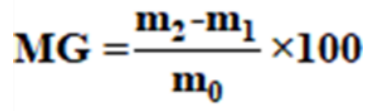

according to equation (3) (Ranoeliarivao, 2011).

With $\mathrm{m}_{0}$ : honey mass $(\mathrm{g}) ; \mathrm{m}_{1}$ : mass of flask and glass beads before extraction $(\mathrm{g}) ; \mathrm{m}_{2}$ : mass of flask with glass beads and MGs after extraction. 
The total carbohydrate content (GT) and the energy value (VE) were determined according to AOAC, (2000) as describe in equations (4) and (5).

GT = 100 - [Ash (\%) + Protein (\%) + Fat (\%) + Moisture (\%)]

VE $=[(\%$ Carbohydrates $\times 4)+(\%$ Protein $\times 4)+(\%$ Fat $\times 9)(\%)]$

\section{Statistical analysis}

All measurements were performed in triplicate and the results of the physicochemical and nutritional parameters were expressed as mean \pm standard deviation (Mean $\pm \mathrm{SD}$ ). A one-way analysis of variance (ANOVA ONE WAY) was used with Origin Pro 9.1 software. The difference between the means was considered significant at the 5\% level. If significant $(\mathrm{p}<0.05)$, the data were analyzed using the Tukey test (multiple comparison test).

Table 1: Information on harvesting sites.

\begin{tabular}{|c|c|c|c|}
\hline Sample & Collection site & Geographic location * & GPS coordinates \\
\hline $\begin{array}{c}M_{1} \text { (pre-harvest) } \\
M_{2} \text { (harvest) }\end{array}$ & $\begin{array}{c}\text { Bouna } \\
\text { (Bounkani region capital) }\end{array}$ & North-East & $\begin{array}{l}9^{\circ} 16^{\prime} 09^{\prime}, \mathrm{N} \\
2^{\circ} 59^{\prime} 42^{\prime}, \mathrm{O}\end{array}$ \\
\hline $\mathbf{M}_{3}$ & $\begin{array}{c}\text { Ferkessédougou } \\
\text { (Tchologo region capital) }\end{array}$ & North & $\begin{array}{l}9^{\circ} 35^{\prime} 37^{\prime \prime} \mathrm{N} \\
5^{\circ} 11^{\prime} 50^{\prime \prime} \mathrm{O}\end{array}$ \\
\hline $\mathbf{M}_{4}$ & $\begin{array}{c}\text { Séguéla } \\
\text { (Worodougou region } \\
\text { capital) }\end{array}$ & North-West & $\begin{array}{l}7^{\circ} 57^{\prime} 36^{\prime \prime} \mathrm{N} \\
6^{\circ} 40^{\prime} 22^{\prime \prime} \mathrm{O}\end{array}$ \\
\hline $\begin{array}{l}\mathbf{M}_{5 \mathrm{~A}} \\
\mathbf{M}_{5 \mathrm{~B}}\end{array}$ & $\begin{array}{c}\text { Biankouma } \\
\text { (Tonkpi region) }\end{array}$ & Center-West & $\begin{array}{l}7^{\circ} 44^{\prime} 00^{\prime \prime} \mathrm{N} \\
7^{\circ} 37^{\prime} 00^{\prime \prime} \mathrm{O}\end{array}$ \\
\hline $\mathbf{M}_{6}$ & $\begin{array}{c}\text { Dimbokro } \\
\text { (N'zi region capital) }\end{array}$ & Center & $\begin{array}{l}6^{\circ} 39^{\prime} \mathrm{N} \\
4^{\circ} 42^{\prime} \mathrm{O}\end{array}$ \\
\hline $\mathbf{M}_{7}$ & $\begin{array}{l}\text { Molonoublé } \\
\text { (Lakes Region) }\end{array}$ & Center & $\begin{array}{l}7^{\circ} 24^{\prime} 00^{\prime \prime} \mathrm{N} \\
4^{\circ} 59^{\prime} 00^{\prime \prime} \mathrm{O}\end{array}$ \\
\hline M8 & $\begin{array}{c}\text { Prikro } \\
\text { (Iffou region) }\end{array}$ & Center-East & $\begin{array}{l}7^{\circ} 38^{\prime} \mathrm{N} \\
3^{\circ} 59^{\prime} \mathrm{O}\end{array}$ \\
\hline M9 & $\begin{array}{c}\text { Guezon } \\
\text { (Middle Cavally Region) }\end{array}$ & West & $\begin{array}{l}6^{\circ} 44^{\prime} 00^{\prime \prime} \mathrm{N} \\
7^{\circ} 07^{\prime} 00^{\prime \prime} \mathrm{O}\end{array}$ \\
\hline $\mathbf{M}_{10}$ & $\begin{array}{c}\text { Dianra } \\
\text { (Béré_Region) }\end{array}$ & Center & $\begin{array}{l}8^{\circ} 46^{\prime} \mathrm{N} \\
6^{\circ} 15^{\prime} \mathrm{O}\end{array}$ \\
\hline M11 & $\begin{array}{c}\text { Abobo market } \\
\text { (Autonomous District of } \\
\text { Abidjan) }\end{array}$ & South & $\begin{array}{l}5^{\circ} 26^{\prime} 00^{\prime \prime} \mathrm{N} \\
4^{\circ} 01^{\prime} 00^{\prime \prime} \mathrm{O}\end{array}$ \\
\hline
\end{tabular}




\section{RESULTS}

The results of the ANOVA analyses reveal a significant $(p<0.05)$ difference between the means of the studied parameters of the eleven honey samples, except for those of the energy value and the moisture. Table 2 indicates organoleptic characteristics obtained from a sample of 30 questioned person, whose ages range from 24 to 40 years. The answers that received more approval were retained. Honey samples from Bouna $\left(\mathrm{M}_{1}\right.$ and $\left.\mathrm{M}_{2}\right)$, Ferkessédougou $\left(\mathrm{M}_{3}\right)$, Séguéla $\left(\mathrm{M}_{4}\right)$, Biankouma $\left(\mathrm{M}_{5 \mathrm{~A}}\right)$, Dimbokro $\left(\mathrm{M}_{6}\right)$, Molonoublé $\left(\mathrm{M}_{7}\right)$, Prikro $\left(\mathrm{M}_{8}\right)$, Guezon ( $\left.\mathrm{M}_{9}\right)$ and Dianra $\left(\mathrm{M}_{10}\right)$ have a liquid texture. Conversely, Bouna $\left(\mathrm{M}_{2}\right)$ and Biankouma $\left(\mathrm{M}_{5 \mathrm{~B}}\right)$ samples have a semi-crystalline texture. The consistency of the samples was syrupy. The different colors observed were orange $\left(\mathrm{M}_{1}\right)$, dark yellow $\left(\mathrm{M}_{5 \mathrm{~A}}, \mathrm{M}_{8}, \mathrm{M}_{9}\right)$ and light $\left(\mathrm{M}_{2}-\mathrm{M}_{4}\right.$, $\mathrm{M}_{6}$ and $\left.\mathrm{M}_{10}\right)$ and dark $\left(\mathrm{M}_{5 \mathrm{~B}}\right.$ and $\left.\mathrm{M}_{7}\right)$ brown.

The physical, physicochemical and nutritional characteristics determined were the density, viscosity, electrical conductivity, refractive index, $\mathrm{pH}$, free acidity, Brix degree, energy value, insoluble matter content, ash, moisture, hydroxydemethylfurfural (HMF), carbohydrates, fats and the protein content. The different values obtained are shown in Table 3. The electrical conductivity of the studied samples varies from $233 \pm 0.02$ to $912 \pm 0.05$ $\mu \mathrm{S} / \mathrm{cm}$, with the lowest value observed in $\mathrm{M}_{1}$ (Bouna pre-harvest honey). Honey samples have an overall electrical conductivity of less than $800 \mu \mathrm{S} / \mathrm{cm}$, apart from Molonoublé honey $\left(\mathrm{M}_{7}\right)(837 \pm 0.08 \mu \mathrm{S} / \mathrm{cm})$ and marketed honey $\left(\mathrm{M}_{11}\right)(912 \pm 0.05 \mu \mathrm{s} / \mathrm{cm})$ which recorded the highest conductivities. All honey samples analyzed show, on the one hand, an acidic character $(3.11 \pm 0.06<\mathrm{pH}<4.20 \pm 0.02)$, and on the other hand, a free acidity of $8.20 \pm 0.01$ to $24.20 \pm 0.01 \mathrm{meq} / \mathrm{kg}$.

The Brix degree of honeys studied varies between $78.60 \pm 0.07$ and $83.80 \pm$ $0.04 \%$. Ferkessédougou honey $\left(\mathrm{M}_{3}\right)$ has the highest Brix degree $(83.80 \pm 0.04 \%)$. The levels of reducing and non-reducing sugars are respectively $63.33 \pm 0.02$ to $79.95 \pm 0.02 \%$ (expressed as glucose) and $2.14 \pm 0.02$ to 7.62 $\pm 0.03 \%$ (expressed as sucrose). The honey samples studied show a very small amount of insoluble matter ranging from $0.12 \pm 0.01$ to $3.17 \pm 0.01 \mathrm{mg}$ per $100 \mathrm{~g}$ of honey. Bouna preharvest $\left(\mathrm{M}_{1}\right)(2.89 \pm 0.02 \mathrm{mg} / 100 \mathrm{~g}$ of honey), Ferkessédougou $\left(\mathrm{M}_{3}\right)(3.01 \pm 0.01 \mathrm{mg} / 100 \mathrm{~g}$ of honey) and Biankouma ( $\mathrm{M}_{5 \mathrm{~A}}$ and $\left.\mathrm{M}_{5 \mathrm{~B}}\right)(3.17 \pm$ 0.01 and $1.53 \pm 0.01 \mathrm{mg} / 100 \mathrm{~g}$ of honey) honeys contain more impurities than the other samples.

Figure 1 provides information on the viscosity of honey samples as a function of temperature $(306.15 \mathrm{~K} ; 311.15 \mathrm{~K} ; 316.15 \mathrm{~K}$ and $321.15 \mathrm{~K})$. Overall, we found out that the viscosity decreases with the increasing of temperature. Biankouma $\left(\mathrm{M}_{5 \mathrm{~B}}\right)$ honey has the highest viscosity rate $(0.805(306.15 \mathrm{~K}) ; 0.695$ $(311.15 \mathrm{~K}) ; \quad 0.551 \quad(316.15 \mathrm{~K})$ and 0.327 $(321.15 \mathrm{~K}))$ followed by the one from Ferkessédougou $\left(\mathrm{M}_{3}\right)$ (0.705 (306.15K); 0.692 $(311.15 \mathrm{~K}) ; \quad 0.549 \quad(316.15 \mathrm{~K}) ; \quad 0.325$ $(321.15 \mathrm{~K}))$. The least viscous sample is the one purchased at the market $\left(\mathrm{M}_{11}\right) \quad(0.144$ (306.15K); 0.115 (311.15K); 0.087 (316.15K; $0.062(321.15 \mathrm{~K}))$. The ash contents of the studied samples vary from $0.3 \pm 0.02$ to $1.24 \pm$ $0.01 \mathrm{mg} / 100 \mathrm{~g}$ of honey. The honeys from Ferkessédougou $\left(\mathrm{M}_{3}\right)$, Biankouma $\left(\mathrm{M}_{5 \mathrm{~A}} ; \mathrm{M}_{5 \mathrm{~B}}\right)$ and Dimbokro $\left(\mathrm{M}_{6}\right)$ had the highest ash contents estimated to $1.24 ; 0.73 ; 1.05$ and 1.21 $\mathrm{mg} / 100 \mathrm{~g}$ of honey respectively.

The moisture percentage of the honey samples varies from 14.40 to $19.70 \%$ with an average of $16.83 \pm 0.06 \%$. Honey from Ferkessédougou $\left(\mathrm{M}_{3}\right)$ had the lowest moisture content $(14.40 \pm 0.06 \%)$, contrary to the honey from Abobo market $\left(\mathrm{M}_{11}\right)$ which had the highest moisture content $(19.70 \pm 0.01 \%)$. Regarding the diastase index, the results obtained indicate that samples $\mathrm{M}_{3}, \mathrm{M}_{4}, \mathrm{M}_{5 \mathrm{~B}}, \mathrm{M}_{7}$ and $\mathrm{M}_{9}$ have the same value (8.33 Schade units). Samples $M_{2}$ and $M_{11}$ have higher diastase indices (10.87 Schade units), while pre-harvest honey $\left(\mathrm{M}_{1}\right)$ appears to exhibit the smallest diastase activity of 4.55 Schade units. Spectrometric analysis of honey samples revealed HMF contents between $10.18 \pm 0.02$ and $166.14 \pm 0.06 \mathrm{mg} / \mathrm{kg}$ with a mean of 44.09 $\pm 0.06 \mathrm{mg} / \mathrm{kg}$ (Table 3$)$. The sample $\left(\mathrm{M}_{5 \mathrm{~B}}\right)$ had 
recorded the lowest HMF content (10.18 \pm 0.02 $\mathrm{mg} / \mathrm{kg}$ ), while the honeys from Abobo market $\left(\mathrm{M}_{11}\right)(166.14 \pm 0.055 \mathrm{mg} / \mathrm{kg})$ and the preharvest from Bouna $\left(\mathrm{M}_{1}\right) \quad(63.57 \pm 0.086$ $\mathrm{mg} / \mathrm{kg}$ ) exhibited the highest rates.

The information on nutritional parameters (fat content, protein and energy value) are highlighted in Table 4 . The fat content (mg / 100g of honey) recorded was oscillates between 0.41 and 0.78 . Honey from Molonoublé $\left(\mathrm{M}_{7}\right)$ showed the lowest content
$(0.41 \pm 0.04)$, while those from Guezon $\left(\mathrm{M}_{9}\right)$ and Abobo market $\left(\mathrm{M}_{11}\right)$ had the highest levels $(0.78 \pm 0.01)$. The protein contents of the honey samples was ranged from 1.23 to $3.50 \%$, the lowest $(1.23 \pm 0.03 \%)$ being observed in the pre-harvest samples from Bouna $\left(\mathrm{M}_{1}\right)$ and Biankouma $\left(\mathrm{M}_{5 \mathrm{~A}}\right)$. For those of Séguéla $\left(\mathrm{M}_{4}\right)$, Molonoublé $\left(\mathrm{M}_{7}\right)$ and Prikro $\left(\mathrm{M}_{8}\right)$, they contain more protein $(3.50 \pm 0.09 \%)$. In general, we found that the honeys from Côte d'Ivoire had similar energy values (Table 4).

Table 2: Organoleptic characteristics of different honey samples collected in nine localities of Côte d'Ivoire.

\begin{tabular}{cccc}
\hline Sample & Taste & Color & Texture \\
\hline $\mathbf{M}_{\mathbf{1}}$ & Caramelized & Yellow Orange & Fluid \\
$\mathbf{M}_{\mathbf{2}}$ & Sugary & Chestnut & Semi crystallized \\
$\mathbf{M}_{\mathbf{3}}$ & Sugary & Dark Chestnut & Fluid \\
$\mathbf{M}_{\mathbf{4}}$ & Much Sugary & Light Chestnut & Fluid \\
$\mathbf{M}_{5 \mathbf{A}}$ & Sugary & Dark Yellow & Fluid \\
$\mathbf{M}_{\mathbf{5}}$ & Less Sugary & Dark Chestnut & Semi crystallized \\
$\mathbf{M}_{\mathbf{6}}$ & Much Sugary & Chestnut & Fluid \\
$\mathbf{M}_{\mathbf{7}}$ & Sugary & Dark Chestnut & Fluid \\
$\mathbf{M}_{\mathbf{8}}$ & Sugary & Dark Yellow & Fluid \\
$\mathbf{M}_{\mathbf{9}}$ & Less Sugary & Dark Yellow & Fluid \\
$\mathbf{M}_{\mathbf{1 0}}$ & Sugary & Light Chestnut & Fluid \\
\hline
\end{tabular}

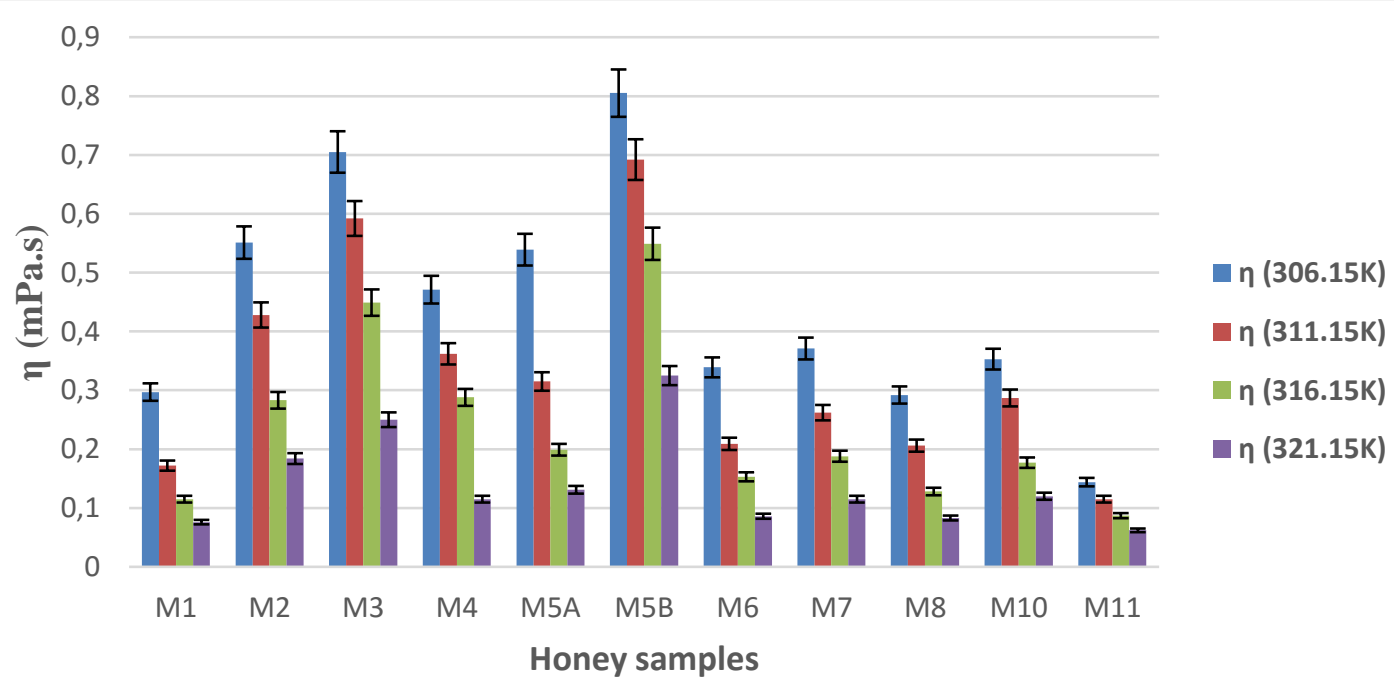

Figure 1: Viscosity of honey samples at different temperatures. 
A. K. YEBOUE et al. / Int. J. Biol. Chem. Sci. 15(2): 846-859, 2021

Table 3: Physicochemical characteristics of honey samples collected in nine localities in Côte d'Ivoire.

\begin{tabular}{|c|c|c|c|c|c|c|c|c|c|c|c|c|}
\hline $\begin{array}{c}\text { Legal } \\
\text { standards } \\
\text { and samples }\end{array}$ & $\begin{array}{l}\text { Refractive } \\
\text { index }\end{array}$ & $\begin{array}{c}\text { Electrical } \\
\text { conductivity } \\
(\mu \mathrm{S} / \mathrm{cm})\end{array}$ & pH & $\begin{array}{c}\text { Free acidity } \\
\text { (meq / kg) }\end{array}$ & $\begin{array}{c}\text { Degree Brix } \\
(\%)\end{array}$ & $\begin{array}{l}\text { Insoluble matter } \\
\text { content } \\
\text { (mg/100g honey) }\end{array}$ & $\begin{array}{l}\text { Ash content } \\
\text { (mg/100g } \\
\text { honey) }\end{array}$ & $\begin{array}{c}\text { Moisture } \\
\text { content } \\
(\%)\end{array}$ & $\begin{array}{c}\text { HMF } \\
\text { (mg / kg } \\
\text { honey) }\end{array}$ & $\begin{array}{c}\text { Diastase } \\
\text { index }\end{array}$ & $\begin{array}{c}\text { Content } \\
\text { reducing } \\
\text { sugars }(\mathrm{g} / \\
\mathbf{1 0 0 g})\end{array}$ & $\begin{array}{l}\text { Sucrose } \\
\text { content }\end{array}$ \\
\hline $\begin{array}{c}\text { Codex } \\
\text { Standards } \\
\text { (Codex, } \\
\text { 2001) }\end{array}$ & & $\begin{array}{c}\leq 800 \mu \mathrm{S} / \mathrm{cm} \\
\text { for nectar } \\
\geq 800 \mu \mathrm{S} / \mathrm{cm} \\
\text { for honeydew }\end{array}$ & 3 at 5 & $\leq 50 \mathrm{meq} / \mathrm{kg}$ & $\geq 65 \mathrm{~g} / 100 \mathrm{~g}$ & $\leq 0.1 \mathrm{~g} / 100 \mathrm{~g}$ & $\leq 0.6 \mathrm{~g} / 100 \mathrm{~g}$ & $\leq 21 \mathrm{~g} / 100 \mathrm{~g}$ & $\begin{array}{c}\leq 60 \mathrm{mg} / \mathrm{kg} \\
\text { of honey }\end{array}$ & $\geq 3$ & $\leq 65 \mathrm{~g} / 100 \mathrm{~g}$ & $\leq 5 \mathrm{~g} / 100 \mathrm{~g}$ \\
\hline $\mathbf{M}_{1}$ & $1.492 \pm 0.012$ & $233 \pm 0.02$ & $3.11 \pm 0.06$ & $12.90 \pm 0.06$ & $80.50 \pm 0.01$ & $2.89 \pm 0.02$ & $0.33 \pm 0.02$ & $17.80 \pm 0.01$ & $63.57 \pm 0.09$ & $4.55 \pm 0.05$ & $79.95 \pm 0.02$ & $6.43 \pm 0.03$ \\
\hline $\mathbf{M}_{2}$ & $1.49 \pm 0.07$ & $537 \pm 0.08$ & $3.96 \pm 0.02$ & $8.20 \pm 0.01$ & $82 \pm 0.04$ & $0.97 \pm 0.05$ & $0.61 \pm 0.01$ & $16.20 \pm 0.07$ & $28.65 \pm 0.05$ & $10.87 \pm 0.03$ & $63.33 \pm 0.02$ & $5.24 \pm 0.05$ \\
\hline $\mathbf{M}_{3}$ & $1.501 \pm 0.057$ & $777 \pm 0.08$ & $4.20 \pm 0.02$ & $17.20 \pm 0.08$ & $83.80 \pm 0.04$ & $3.01 \pm 0.01$ & $1.24 \pm 0.01$ & $14.40 \pm 0.06$ & $32.49 \pm 0.01$ & $8.33 \pm 0.02$ & $69.81 \pm 0.02$ & $2.14 \pm 0.02$ \\
\hline $\mathbf{M}_{4}$ & $1.495 \pm 0.073$ & $766 \pm 0.03$ & $3.75 \pm 0.06$ & $13 \pm 0.06$ & $79.90 \pm 0.07$ & $0.80 \pm 0.07$ & $0.32 \pm 0.02$ & $16.50 \pm 0.07$ & $40.12 \pm 0.05$ & $8.33 \pm 0.01$ & $72.71 \pm 0.01$ & $3.10 \pm 0.01$ \\
\hline $\mathbf{M}_{5 \mathrm{~A}}$ & $1.494 \pm 0.071$ & $431 \pm 0.02$ & $3.61 \pm 0.04$ & $9.80 \pm 0.02$ & $81.40 \pm 0.07$ & $3.17 \pm 0.01$ & $0.73 \pm 0.01$ & $16.80 \pm 0.07$ & $19.32 \pm 0.08$ & $6.49 \pm 0.03$ & $68.38 \pm 0.02$ & $4.05 \pm 0.01$ \\
\hline $\mathbf{M}_{5 \mathrm{~B}}$ & $1.496 \pm 0.073$ & $720 \pm 0.04$ & $3.61 \pm 0.04$ & $9.80 \pm 0.01$ & $81.40 \pm 0.07$ & $1.53 \pm 0.01$ & $1.05 \pm 0.01$ & $16.20 \pm 0.07$ & $10.18 \pm 0.02$ & $8.33 \pm 0.01$ & $72.00 \pm 0.02$ & $7.62 \pm 0.03$ \\
\hline $\mathbf{M}_{6}$ & $1.491 \pm 0.083$ & $790 \pm 0.05$ & $3.50 \pm 0.06$ & $13.60 \pm 0.08$ & $80.20 \pm 0.01$ & $0.61 \pm 0.08$ & $1.21 \pm 0.01$ & $18.10 \pm 0.08$ & $49.07 \pm 0.06$ & $6.49 \pm 0.03$ & $71.76 \pm 0.01$ & $4.29 \pm 0.03$ \\
\hline $\mathbf{M}_{7}$ & $1.495 \pm 0.072$ & $837 \pm 0.08$ & $3.16 \pm 0.03$ & $24.20 \pm 0.01$ & $80.60 \pm 0.04$ & $0.12 \pm 0.01$ & $0.55 \pm 0.02$ & $16.70 \pm 0.07$ & $26.97 \pm 0.08$ & $8.33 \pm 0.06$ & $77.14 \pm 0.01$ & $2.38 \pm 0.01$ \\
\hline M8 & $1.495 \pm 0.083$ & $756 \pm 0.01$ & $3.26 \pm 0.09$ & $17.60 \pm 0.08$ & $79.80 \pm 0.07$ & $0.79 \pm 0.02$ & $0.59 \pm 0.01$ & $16.50 \pm 0.08$ & $31.46 \pm 0.05$ & $6.49 \pm 0.01$ & $69.62 \pm 0.03$ & $6.90 \pm 0.06$ \\
\hline M9 & $1.495 \pm 0.073$ & $486 \pm 0.04$ & $3.39 \pm 0.09$ & $12.50 \pm 0.07$ & $81.70 \pm 0.07$ & $0.51 \pm 0.01$ & $0.30 \pm 0.02$ & $16.50 \pm 0.07$ & $39.74 \pm 0.06$ & $8.33 \pm 0.05$ & $69.90 \pm 0.03$ & $5.48 \pm 0.08$ \\
\hline $\mathbf{M}_{10}$ & $1.495 \pm 0.012$ & $774 \pm 0.05$ & $3.75 \pm 0.08$ & $13 \pm 0.06$ & $80.80 \pm 0.04$ & $0.24 \pm 0.01$ & $0.54 \pm 0.01$ & $16.50 \pm 0.01$ & $21.41 \pm 0.06$ & $6.49 \pm 0.07$ & $65.24 \pm 0.03$ & $7.38 \pm 0.04$ \\
\hline $\mathbf{M}_{11}$ & $1.487 \pm 0.057$ & $912 \pm 0.05$ & $3.88 \pm 0.08$ & $11.50 \pm 0.08$ & $78.60 \pm 0.07$ & $0.60 \pm 0.04$ & $0.57 \pm 0.02$ & $19.70 \pm 0.01$ & $\begin{array}{c}166.14 \pm \\
0.06\end{array}$ & $8.33 \pm 0.04$ & $65.62 \pm 0.02$ & $5.24 \pm 0.04$ \\
\hline Mean & & $668.25 \pm 0.05$ & $3.60 \pm 0.06$ & $13.61 \pm 0.05$ & $80.89 \pm 0.05$ & $1.27 \pm 0.03$ & $0.67 \pm 0.01$ & $16.83 \pm 0.06$ & $44.09 \pm 0.06$ & $7.61 \pm 0.03$ & $70.46 \pm 0.02$ & $5.02 \pm 0.07$ \\
\hline
\end{tabular}


Table 4: Nutritional data of the analyzed honey samples.

\begin{tabular}{cccc}
\hline Honey samples & $\begin{array}{c}\text { Fat content } \\
\text { (mg / 100g of honey })\end{array}$ & $\begin{array}{c}\text { Protein content } \\
\text { (in \%) }\end{array}$ & $\begin{array}{c}\text { Energy value } \\
\text { (kcal / 100g of honey) }\end{array}$ \\
\hline $\mathbf{M}_{1}$ & $0.69 \pm 0.02$ & $1.23 \pm 0.13$ & $402.13 \pm 0.08$ \\
$\mathbf{M}_{\mathbf{2}}$ & $0.58 \pm 0.02$ & $2.28 \pm 0.16$ & $400.46 \pm 0.27$ \\
$\mathbf{M}_{3}$ & $0.59 \pm 0.02$ & $2.10 \pm 0.06$ & $396.39 \pm 0.26$ \\
$\mathbf{M}_{\mathbf{4}}$ & $0.77 \pm 0.01$ & $3.50 \pm 0.29$ & $401.5 \pm 0.28$ \\
$\mathbf{M}_{5 \mathbf{A}}$ & $0.58 \pm 0.02$ & $1.23 \pm 0.13$ & $399.98 \pm 0.57$ \\
$\mathbf{M}_{5 \mathbf{B}}$ & $0.43 \pm 0.02$ & $1.75 \pm 0.43$ & $397.95 \pm 0.55$ \\
$\mathbf{M}_{6}$ & $0.59 \pm 0.05$ & $2.98 \pm 0.57$ & $398.11 \pm 0.06$ \\
$\mathbf{M}_{7}$ & $0.41 \pm 0.04$ & $3.50 \pm 0.29$ & $399.85 \pm 0.49$ \\
$\mathbf{M}_{8}$ & $0.77 \pm 0.05$ & $3.50 \pm 0.29$ & $401.49 \pm 0.08$ \\
$\mathbf{M}_{9}$ & $0.78 \pm 0.02$ & $1.75 \pm 0.43$ & $402.7 \pm 0.40$ \\
$\mathbf{M}_{10}$ & $0.59 \pm 0.02$ & $3.15 \pm 0.09$ & $400.79 \pm 0.46$ \\
$\mathbf{M}_{11}$ & $0.78 \pm 0.01$ & $2.28 \pm 0.16$ & $401.62 \pm 0.04$ \\
\hline
\end{tabular}

\section{DISCUSSION}

The organoleptic parameters indicated a similarity in the texture of the different honey samples. However, the samples from Bouna $\left(\mathrm{M}_{2}\right)$ and Biankouma $\left(\mathrm{M}_{5 \mathrm{~B}}\right)$ have a semicrystalline texture, which would indicate their high glucose content. Indeed, the textures of honeys are dependent on the glucose/fructose ratio (Dailly, 2008). From nutritional viewpoint, the texture as well as the sweetness are not a handicap. The Brix degree reflects the quantity of sugar (in g) contained in $100 \mathrm{~g}$ of honey cooled at $20{ }^{\circ} \mathrm{C}$ (Dailly, 2008). The honey from Ferkessédougou $\left(\mathrm{M}_{3}\right)$ having the highest Brix degree $(83.80 \pm 0.04 \%)$ appears as the sweetest honey. Good quality honey is usually thick and viscous. The viscosity of honey depends on moisture content, the sugar composition and the colloidal substances. It also depends on temperature (Amri, 2006; Zaikina, 2012). The results obtained showed that the viscosity of the honeys submitted for analysis decreases considerably with increasing temperature (Figure 1). The highest viscosity was observed in commercial honey
$\left(\mathrm{M}_{11}\right)$ and that is actually related to its high moisture content $(19.70 \pm 0.01 \%)$.

All the samples studied could be classified as flower honeys, except for the Molonoublé honey (M7) $(837 \pm 0.08 \mu \mathrm{S} / \mathrm{cm})$ and the commercial honey (M11) $(912 \pm 0.05$ $\mu \mathrm{S} / \mathrm{cm}$ ), which could be honeydew honeys. Indeed, flower honeys have an electrical conductivity lower than $0.8 \mathrm{mS} / \mathrm{cm}$, whereas honeydew honeys have an electrical conductivity higher than $0.8 \mathrm{mS} / \mathrm{cm}$ (Bogdanov et al., 1999; European Commission, 2001). In addition, there is a correlation between electrical conductivity and the concentration of mineral substances, the higher the ash content, the greater the electrical conductivity would be (Moussaoui, 2011; Zerrouk et al., 2011; Benameur, 2014; Belhaj et al., 2015). Among the honeys studied, Bouna pre-harvest honey $\left(\mathrm{M}_{1}\right)$ has the lowest electrical conductivity $(233 \pm 0.02 \mu \mathrm{S} / \mathrm{cm})$, which is confirmed by a lower ash content $(0.33 \pm 0.02 \%)$, while Molonoublé honey $\left(\mathrm{M}_{7}\right)$ and commercial honey $\left(\mathrm{M}_{11}\right)$ had respectively had the highest conductivities $(837 \pm 0.077$ and 
$912 \pm 0.05 \mu \mathrm{S} / \mathrm{cm})$ and ash contents $(0.55 \pm$ $0.02 \%$ and $0.57 \pm 0.02 \%$ ).

The acidity of honey is a criterion of its bactericidal activity and its quality (Naman et al., 2005). All samples of honey studied have some $\mathrm{pH}$ between 3.11 and 4.20; which indicates, on the one hand, that they are acidic, therefore antibacterial, and on the other hand, that they are of nectar origin (Gonnet, 1986). The $\mathrm{pH}$ values obtained are similar to those reported in literature concerning honeys from Portugal (3.45 - 4.70) (Silva et al., 2009), Saudi Arabia (3.03 - 4.73) (Alqarni et al., 2012), Algeria (3.62 - 4.10), (Ouchemoukh, 2012), Iran (2.6 - 4.4) (Mahmoodi-Khaledi et al., 2017), Morocco (3.39 - 4, 19) (Belhaj et al., 2015), Congo (3.9 - 4.2) (Ngoma et al., 2018) and Côte d'Ivoire's mainly in the region of Worodougou region (3.7 - 4.77) (Diomandé et al., 2018). Free acidity is an important factor in the enzymatic processes of honey. Also, it provides information on the taste of the honey (Bogdanov et al., 1999; Da Silva et al., 2016). The free acidity values $(8.20 \pm 0.01$ to $24.20 \pm$ $0.01 \mathrm{meq} / \mathrm{kg}$ ) obtained are less than $50 \mathrm{meq} / \mathrm{kg}$, the limit authorized by the international regulations (Codex, 2001). Importantly, these results show in the samples of Ivorian's honey, the presence in of small quantities of compounds responsible for undesirable fermentation.

Honeys from Côte d'Ivoire have low moisture contents (19.7\%), which is in conformity with the proposed standard $(\leq 21$ g/100g) (Bogdanov et al., 1999; Codex, 2001). These results allow to conclude that the studied honey samples present a good degree of maturity and could be stored over a long period of time without losing their natural properties. In addition, they provide some information on the stability of honey against fermentation during the storage (De Rodriguez et al., 2004; Küçük et al., 2007; Saxena et al., 2010; Zaikina, 2012). The humidity values are similar to those of Iranian (from 15.40 to 18.40) (Mahmoodi-Khaledi et al., 2017), Tunisian (from 17.27 to 19.80), (Boussaid et al., 2018), Emirati (15 to $19.5 \%$ ) (Alyammahi, 2018) and Brazilian (from 15.93 to 20.80)
(Rizelio et al., 2020) honeys. The honeys from Côte d'Ivoire were distinguished by their high amount of soluble dry matter, expressed in degrees Brix (from 78.6 to $83.8 \%$ ). This parameter gives us some information on the maturity and the nutritional value of studied honey (Bogdanov et al., 1999; Codex, 2001). Considering the obtained values, we can affirm that Ivorian honeys can be classified as nectar origin, because they have sugar content greater than 60\% (Bogdanov et al., 1999). The rates obtained are close to those reported by Ngoma et al., 2018 (from 79 to 80\%). In addition, they are significantly higher than those of Séguéla honey ( $21 \pm 0.44$ and $24 \pm 0.01 \%$ ) (Diomande et al., 2018). This difference could be explained by the nature of the flowers butinated and the harvesting period (Dailly, 2008).

The content of reducing sugars in all samples evaluated is within the limits established by Codex Alimentarius Commission (Codex, 2001). On the other hand, out of the 11 honey samples studied, the sucrose contents of five samples $\left(\mathrm{M}_{1}, \mathrm{M}_{8}-\mathrm{M}_{11}\right)$ didn't comply with the international standards. In general, natural honey has a low sucrose content (maximum $5 \mathrm{~g} / 100 \mathrm{~g}$ of honey), which may decrease during the storage due to the selfinversion process (Dailly, 2008; Zaikina, 2012). Thus, the high rates recorded in this study could be attributed to the overfeeding of bees with sugar syrup or the earlier harvest of the honey (Da Silva et al., 2016). However, some honeys such as citrus, rosemary and alfalfa contain a higher percentage of sucrose (maximum $10 \mathrm{~g} / 100 \mathrm{~g}$ of honey). This is the case with lavender honey in which the proportion in sucrose is estimated at $15 \mathrm{~g} / 100$ g (Codex, 2011).

The high levels of insoluble matter in the honeys, especially those gathered in Bouna pre-harvest $\left(\mathrm{M}_{1}\right)$, Ferkessédougou $\left(\mathrm{M}_{3}\right)$ and Biankouma ( $\mathrm{M}_{5 \mathrm{~A}}$ and $\mathrm{M}_{5 \mathrm{~B}}$ ) honeys indicate that there are impurities in these nectars deriving from the pollen grains and other debris, which were not completely removed during the maturation phase (Huchet et al., 1996). Ferkessédougou $\left(\mathrm{M}_{3}\right)$, Biankouma $\left(\mathrm{M}_{5 \mathrm{~A}} ; \mathrm{M}_{5 \mathrm{~B}}\right)$ and Dimbokro $\left(\mathrm{M}_{6}\right)$ honeys have some ash 
contents higher than the imposed standard ( $\leq$ $0.6 \mathrm{~g} / 100 \mathrm{~g}$ ) (Bogdanov et al., 1999; Codex, 2001), which could reveal that in addition to nectar, they may contain honeydew. According to Bogdanov, honeydew honey or the mixture of honeydew and nectar have ash contents less than or equal to $1.2 \mathrm{~g} / 100 \mathrm{~g}$ of honey (Bogdanov, 1999). In addition, these high values could indicate some anthropogenic activities around the apiaries. This is the case of Ferkessédougou and Dimbokro apiaries, which are established in crops of Anacardium Occidental (Anarcadiaceae), sometimes require the use of pesticides. As for the apiaries of Biankouma, they are installed in a rural area. Thus, the determination of the mineral content of honey samples provides an indication of the state of environmental pollution and the geographical and floral origins of the honey (Acquarone et al., 2007).

The diastase index and the HMF content are some quality indicators for accurate information on the storage and heat treatment conditions of the honey (Bogdanov et al., 1999). Indeed, the evaluation of HMF content (degradation product of fructose) allows to control the honey processing technology, namely the heating, duration and the storage conditions of honey, and also, if possible, to detect the presence of adulteration by artificially inverted sugar (Perdrix, 2003; Moussaoui, 2011; Pasias et al., 2017). The HMF contents obtained (Table 2) for most of the honeys comply with the standards values ( $\leq$ $60 \mathrm{mg} / \mathrm{kg}$ of honey) set by the international regulations (Bogdanov et al., 1999; Codex, 2001), excepted Bouna's pre-harvest honey $\left(\mathrm{M}_{1}\right)(63.57 \pm 0.09 \mathrm{mg} / \mathrm{kg}$ of honey $)$ and the sample purchased commercially $\left(\mathrm{M}_{11}\right)(166.14$ $\pm 0.06 \mathrm{mg} / \mathrm{kg}$ of honey). The high HMF content observed in commercial honey may be due to its adulteration by the addition of invert syrup or by poor packaging and the storage conditions (Capuano and Fogliano, 2011; Guler et al., 2014; Da Silva et al., 2016). According to Perdrix (2003), the use of inappropriate containers exposes honey to heat and to several chemical reactions including dehydration of sugars leading to the formation of HMF. Furthermore, the value of the diastase index $(8.33 \pm 0.04)$ observed in commercial honey $\left(\mathrm{M}_{11}\right)$ confirms that it has undergone a heat treatment or a bad storage condition (Guler et al., 2014; Da Silva et al., 2016). The number of diastases (4.55) less than 8 Schade units for the sample of pre-harvest honey $\left(\mathrm{M}_{1}\right)$ indicates that its enzyme content would be low (Guler et al., 2014; Da Silva et al., 2016).

Lipids are present in honey in small quantities and their presence could be due to the existence of some waxy debris, which escapes the filtration process (Louveaux, 1985). The lipid contents obtained for Ivorian honeys are lower than those mentioned in literature (Ranoeliarivao, 2011) for honeys from three melliferous regions of Madagascar namely Niaouli, Analanjirofo and Atsimo Atsinanana, whose lipid contents vary respectively from 0.08 to 0.7 ; from 0.08 to 0.56 and from 0.16 to $0.7 \mathrm{~g} / 100 \mathrm{~g}$ of honey. The protein content in all the honey samples are higher than those estimated by international standards $(0.26 \%$ on average with a maximum of $0.83 \%$ ) (Rossant, 2011). As a result, the high rate recorded in Ivorian honey could be explained by the presence in profusion of pollen, nectar and / or the body of bees, which are very often crushed during extraction, thus escaping filtration (Gonnet, 1986; Zaikina, 2012). Finally, the nutritional value of Ivorian honeys is due to their high energy value (> 320 kcal per $100 \mathrm{~g}$ ). Indeed, honey allows rapid recovery of expended muscle energy. It is recommended for people who do hard physical work (Zaikina, 2012). Thus, the high energy value of honey from Côte d'Ivoire could be responsible to its therapeutic and nutritional properties (Rossant, 2011).

\section{Conclusion}

The physical, physicochemical and nutritional characteristics of honeys from different localities in Côte d'Ivoire generally comply with the standards required by the Codex Alimentarius Commission. The results of this study allowed us to classify from Côte d'Ivoire honeys in the category of nectar honeys. The acidity indicators show the 
bacterial activity of the honeys. Nutritional parameters showed variable and not negligible proportions of lipids, carbohydrates and proteins. In addition, the honeys from Côte d'Ivoire have presented a high energy value. Ultimately, based on the data collected on honeys produced in Côte d'Ivoire, new research horizons are opening up for the consolidation of their consumption and application.

\section{COMPETING INTERESTS}

The authors declare that they have no competing interests.

\section{AUTHORS' CONTRIBUTIONS}

This work was carried out in collaboration with all the authors. MBJA and KGRM designed the study and wrote the protocols. YKA, ADA and KKC carried out the experiments and statistical analyses. YKA, KGRM and MBJA wrote the first draft of the manuscript. SEA and BYA made corrections to the different drafts with comments and suggestions. KGRM, MBJA and BYA wrote the final draft. Finally, all authors read and approved the final manuscript.

\section{ACKNOWLEDGEMENTS}

We are very grateful to the beekeepers for the different honey samples.

\section{REFERENCES}

Aboud F, De Pasquale C, Sinacori A, Massi S, Conte P, Alonzo G. 2011. Palynological, physico-chemical and aroma characterization of Sicilian honeys. Journal of ApiProduct and ApiMedical Science, $\quad 3(4)$ : $\quad$ 164-173. DOI: 10.3896/IBRA.4.03.4.03

Acquarone C, Buera P, Elizalde B. 2007. Pattern of $\mathrm{pH}$ and electrical conductivity upon honey dilution as a complementary tool for discriminating geographical origin of honeys. Food Chemistry, 101(2): 695-703. DOI: 10.1016/j.foodchem.2006.01.058
Al-Farsi M, Al-Belushi S, Al-Amri A, AlHadhrami A, Al- Rusheidi M, Al-Alawi A. 2018. Quality evaluation of Omani honey. Food Chemistry, 262: 162-167. DOI:10.1016/j.foodchem.2018.04.104

Alqarni AS, Owayss AA, Mohamed AA. 2012. Physicochemical characteristics, total phenols and pigments of national and international honeys in Saudi Arabia. Arabia Journal Chemistry, 1-7. DOI: 10.1016/j.arabic.2012.11.013

Alyammahi MM. 2018. Physicochemical characteristics of mono floral Emirati honey. Thesis Master, United Arab Emirates University, United Arab Emirates, 75 p.

Amri A. 2006. Évaluation physico-chimique et détermination de l'origine botanique de quelques variétés de miel produites à l'est algérien. Mémoire de Magistère, Université Badji Mokhtar-Annaba, Annaba, $122 \mathrm{p}$.

AOAC. 2000. Official Methods of Analysis of the Association of Official Agriculture Chemists $\left(17^{\text {th }}\right.$ edn). AOAC: Washington DC, USA.

Belhaj O, Oumato J, Zrira S. 2015. Étude physico-chimique de quelques types de miels marocains. Rev. Mar. Sci. Agron. Vét., 3(3): 71-75.

Benameur A. 2014. Etude physico-chimique et pollinique du miel d'Eucalyptus globulus de la région de Tlemcen. Mémoire de Master, Université Abou Bakr Belkaid, Tlemcen, $86 \mathrm{p}$.

Bertoncel J, Doberšek U, Jamnik M, Golob T. 2007. Analytical, Nutritional and Clinical Methods, Evaluation of the phenolic content, antioxidant activity and colour of Slovenian honey. Food Chemistry, 105(2): $\quad 822-828 . \quad$ DOI: 10.1016/j.foodchem.2007.01.060

Bogdanov S, Lüllmann C, Martin P, Ohe W, Russmann H, Vorwohl G, Oddo L, Sabatini A-G, Marcazzan G, Piro R, Flamini C, Morlot M, Lhéritier J, Borneck R, Marioleas P, Tsigouri A, 
Kerkvliet J, Ortiz A, Ivanov T, D'Arcy B, Mossel B, Vit P. 1999. Honey quality and international regulatory standards: review by the International Honey Commission. Bee World, 80(2): 61-69. DOI: 10.1080/0005772X.1999.11099428

Bogdanov S, Martin P, Lüllmann C. 1997. Harmonized methods of the European Honey Commission. Apidologie, 27: 159.

Bogdanov S, Ruoff K, Persano Oddo L. 2004. Physico-chemical methods for characterisation of unifloral honeys: A review. Apidologie, 35(1): 4-17.

Bogdanov S. 2009. Harmonised methods of the International Honey Commission. IHC. http://www.ihc-

platform.net/ihcmethods2009.pdf

Boussaid A, Chouaibi M, Rezig L, Hellal R, Dons F, Ferrari G, Hamdi S. 2018. Physicochemical and bioactive properties of six honey samples from various floral origins from Tunisia. Arabian Journal of Chemistry, 11(2): 265-274. DOI: 10.1016/j.arabjc.2014.08.011

Brudzynski K. 2006. Effect of hydrogen peroxide on antibacterial activities of Canadian honeys. Canadian Journal of Microbiology, 52(12): 1228-1237. DOI: https://doi.org/10.1139/w06-086

Capuano E, Fogliano V. 2011. Acrylamide and 5-hydroxymethylfurfural (HMF): A review on metabolism, toxicity, occurrence in food and mitigation strategies. Food Science and Technology, 44(4): 793-810. DOI: https://doi.org/10.1016/j.lwt.2010.11.002

Codex Secretariat. 2017. La science des normes alimentaires - sur le chemin qui mène de la trente-neuvième à la quarantième session de la Commission du Codex Alimentarius. FAO, Rome, Italy.

Codex. 2001. Programme mixte FAO/OMS sur les Normes alimentaires : Commission du Codex alimentarius. Alinorm., 1(25): 131.
Da Silva PM, Gauche C, Gonzaga LV, Costa ACOC, Fett R. 2016. Honey: Chemical composition, stability and authenticity. Food Chemistry, 196: 309-323. DOI: 10.1016/j.foodchem.2015.09.051

Dailly H. 2008. Le réfractomètre, un outil essentiel. Abeilles \& Cie, 122: 30-32.

De Rodriguez GO, De Ferrer BS, Ferrar A, Rodriguez B. 2004. Characterization of honey produced in Venezuela. Food Chemistry, 84: 499-502. DOI: 10.1016/S0308-8146(02)00517-4

Diomandé M, Coulibaly S, Coulibaly KAC, Bohoua LG. 2018. Identification de plantes mellifères et propriétés physicochimiques de miels de la région $\mathrm{du}$ Worodougou, Côte d'Ivoire. International Journal of Current Research, 10(4): 67583-67590.

European Commission. 2001. Council Directive 2001/110/EC of 20 December 2001 relating to honey. European Commission. Retrieved from http://www.ihcplatform.net/honeydirective2001.pdf

Gonnet M. 1986. L'analyse des miels. Description de quelques méthodes de contrôle de qualité. Bul. Tech. Apic., 13(1): 17-36.

GOST-19792. 2013. Miel Naturel Spécifications (édn). Interstandard: Russie.

Guler A, Bakan A, Nisbet C, Yavuz O. 2007. Determination of important biochemical properties of honey to discriminate pure and adulterated honey with sucrose (Saccharum officinarum) Syrup. Food Chemistry, $\quad \mathbf{1 0 5}(3)$ : 1119-1125. DOI: 10.1016/j.foodchem.2007. 02.024

Guler A, Kocaokutgen H, Garipoglu AV, Onder H, Ekinci D, Biyik S. 2014. Detection of adulterated honey produced by honeybee (Apis mellifera L.) colonies fed with different levels of commercial industrial sugar ( $\mathrm{C}_{3}$ and $\mathrm{C}_{4}$ plants) syrups by the carbon isotope ratio analysis. Food 
Chemistry, 155: 155-160. DOI: 10.1016/j.foodchem.2014.01.033

Huchet E, Coustel J, Guinot L. 1996. Les constituants chimiques du miel. Méthode d'analyse chimique. Ecole nationale supérieure des industries agricoles et alimentaire, France.

Kabré E, Soulama D, Bandé M, Karfo R, Bazié R, Nikiéma F, Sakandé J. 2020. Quantitative determination of chemical and biochemical parameters during « soumbala » manufacturing process in two communities of Burkina Faso. Int. J. Biol. Chem. Sci., 14(9): 3001-3017. DOI: https://dx.doi.org/10.4314/ijbcs.v14i9.4

Kouassi DF, N'guessan KE, Ouattara D, Coulibaly S. 2018. La cueillette, la production et la commercialisation du miel dans le Département de Katiola (Centre-Nord, Côte d'Ivoire). International Journal of Biological and Chemical Sciences, 12(5): 2212-2225. DOI: $10.4314 /$ ijbcs.v12i5.22

Küçük M, Kolaylı S, Karaoğlu Ş, Ulusoy E, Baltac1 C, Candan F. 2007. Biological activities and chemical composition of three honeys of differents types from Anatolia. Food Chemistry, 100(2): 526534.

DOI: https://doi.org/10.1016/j.foodchem.2005. 10.010 .

Louveaux J. 1985. Les Abeilles et leur Elevage. Édition Hachette Nouvelles Encyclopédies des Connaissances Agricoles : France.

Mahmoodi-Khaledi E, Lozano-Sanchez J, Bakhouche, Habibi-Rezaei M, Sadeghian I, Segura-Carretero A. 2017. Physicochemical properties and biological activities of honeys from different geographical and botanical origins in Iran. European Food Research and Technology, 243(6): 1019-1030. DOI:10.1007/s00217-016-2811-0

Moussaoui N. 2011. Analyse sensorielle de quelques miels du sud Algérien. Mémoire
d'Ingénieur, Université Kasdi Merbah, Ouargla, 98 p.

Naila A, Flint SH, Sulaiman AZ, Ajit A, Weeds Z. 2018. Classical and novel approaches to the analysis of honey and detection of adulterants. Food Control, 90: 152-165. DOI:10.1016/j.foodcont.2018.02.027

Naman M, Faid M, El Adlouni C. 2005. Microbiological and physico-chemical properties of Moroccan honey. International Journal of Agriculture \& Biology, 7: 773-776.

Ngoma BC, Ilanga OF, Kwemani SMG, Efoto EL. 2018. Quelques paramètres physicochimiques des miels de quatre provinces de la République Démocratique du Congo en relation avec leur qualité et leur stabilité. Afrique Science, 14(5): 415 424.

Ouchemoukh S, Louaileche H, Schweitzer P. 2007. Physicochemical characteristics and pollen spectrum of some Algerian honeys. Food Chemistry, 18(1): 52-58. DOI: $10.1016 /$ j.foodcont.2005.08.007

Pasias IN, Kiriakou IK, Proestos C. 2017. HMF and diastase activity in honeys: A fully validated approach and a chemometric analysis for identification of honey freshness and adulteration. Food Chemistry, 229(15): 425-431. DOI: https://doi.org/10.1016/j.foodchem.2017. 02.084

Perdrix JL. 2003. Critères de qualité du miel. Bulletin de liaison $\mathrm{N}^{\circ} 41$.

Ranoeliarivao VM. 2011. Caractérisation alimentaire des miels malgaches en vue d'une authentification : cas des miels de Niaouli. Mémoire de DEA, Université d'Antananarivo, Antananarivo, p. 103.

Rizelio VM, Tenfen L, Gonzaga LV, Borges G, Da Silva C, Biluca FC, Schulz M, Costa ACO, Fett R. 2020. Physicochemical and bioactive properties of Southern Brazilian Apis mellifera L. honeys. Journal of Apicultural Research, 59(5): 910-916. DOI: $10.1080 / 00218839.2020 .1735760$ 
Rossant A. 2011. Le miel, un composé complexe aux propriétés surprenantes. Thèse de Doctorat, Université de Limoges, Limoges, 132 p.

Savadogo S, Assi KC, N'guessan K. 2018. Note sur la place de l'apiculture dans la société Baoulé en Côte d'Ivoire : cas de deux villages du District de Yamoussoukro. Geo-Eco-Trop., 42(1): 199-206.

Saxena S, Gautam S, Sharma A. 2010. Physical, biochemical and antioxidant properties of some Indian honeys. Food Chemistry, 118: 391-397. DOI: 10.1016/j.foodchem. 2009.05.001

Silva LR, Videira R, Monteiro Andreia P, Valentão P, Andrade PB. 2009. Honey from luso Region (Portugal): physicochemical characteristics and mineral contents. Microchemical Journal, $\quad$ 93(1): 73-77. https://doi.org/10.1016/j.microc.2009.05. 005.

Tabet E. 2009. Etudes microbiologiques et physicochimiques des laits caprins et technologie fromagère améliorée : Cas du lait "Baladi"' du Liban. Thèse de Doctorat, Université de Sassari, Sassari, p. 75.

Ustok FI, Tari C, Gogus N. 2007. Solid-state production of polygalacturonase by Aspergillus sojae ATCC 20235. J. Biotechnol., 127: 322-334.

Zaikina VI. 2012. Examen du Miel et Méthodes de Détection de sa Falsification ( $3^{\mathrm{e}}$ édn). Société d'Edition et de Négoce : Dashkov.

Zeni J, Gomes J, Ambroszini E, Toniazzo G, D'Oliveira D, Valduga E. 2013. Experimental design applied to the optimization and partial characterization of pectin-methyl-esterase from a newly isolated Penicillium brasilianum. Afr. J. Biotechnol., 12(40): 5886-5896.

Zerrouk HS, Fallico BG, Arena EA, Gabriele FB, Larbi AB. 2011. Quality Evaluation of Some Honey from the Central Region of Algeria. Jordan Journal of Biological Sciences, 4(4): 243-248. 